\title{
PENGARUH CUSTOMER ACCOUNTING DAN CUSTOMER ORIENTATION TERHADAP KINERJA ORGANISASI
}

\author{
Putri Inti Amelia Lubis ${ }^{1}$, Linda Hetri Suriyanti ${ }^{2}$, Zul Azmi ${ }^{3}$ \\ Program Studi Akuntansi FEB Universitas Muhammadiyah Riau \\ putriintilubis@gmail.com;
}

\begin{abstract}
This study aims to examine the effect of customer accounting as a strategic management accounting techniques and customer orientation on organizational performance. The population in this study is the Micro, Small and Medium Enterprises (SMEs) in the culinary field in Pekanbaru. Samples were selected using a purposive sampling method and 85 businesses were sampled. The analytical method used is multiple regression analysis. The results showed that customer accounting as a strategic management accounting techniques influenced organizational performance and customer orientation influenced organizational performance. The F Test shows that the customer accounting and customer orientation variables together affect the performance of the organization.
\end{abstract}

Keywords: Organizational Performance, Customer Accounting, Customer Orientation.

\begin{abstract}
ABSTRAK
Penelitian ini bertujuan untuk menguji pengaruh customer accounting sebagai strategic management accounting techniques dan customer orientation terhadap kinerja organisasi.Populasi dalam penelitian ini adalah Usaha Mikro Kecil Menengah (UMKM) di bidang kuliner yang ada di Pekanbaru.Sampel dipilih menggunakan metode purposive sampling dan diperoleh 85 usaha yang menjadi sampel.Metode analisis digunakan adalah analisis regresi berganda.Hasil penelitian menunjukkan bahwa customer accounting sebagai strategic management accounting techniques berpengaruh terhadap kinerja organisasi dan customer orientation berpengaruh terhadap kinerja organisasi. Secara Uji F, menunjukkan bahwa variabel customer accounting dan customer orientation bersama-sama berpengaruh terhadap kinerja organisasi.
\end{abstract}

Kata kunci: Kinerja Organisasi, Akuntansi Pelanggan, Orientasi Pelanggan.

\section{PENDAHULUAN}

\section{Latar Belakang}

Kinerja merupakan gambaran mengenai tingkat pencapaian pelaksanaan suatu program kegiatan atau kebijakan dalam mewujudkan sasaran, tujuan, visi dan misi organisasi yang dituangkan melalui perencanaan strategis suatu organisasi.Kinerja dapat diketahui dan diukur jika individu atau sekelompok karyawan telah mempunyai 
kriteria atau standar keberhasilan tolak ukur yang telah ditetapkan oleh organisasi.Pengukuran kinerja menjadi hal yang sangat penting bagi manajemen untuk melakukan evaluasi terhadap performa organisasi dan perencanaan tujuan dimasa mendatang.Oleh karena itu, penilaian kinerja penting dilakukan pada sebuah organisasi termasuk UMKM.

UMKM merupakan salah satu jenis usaha yang ada di Indonesia.Sebagai sebuah organisasi bisnis yang bersifat mandiri, UMKM mempunyai peranan yang penting dalam pertumbuhan ekonomi dan industri suatu Negara. Analisis yang dilakukan oleh Kementerian Perindustrian (Kemenperin) menyatakan bahwa UMKM memiliki kontribusi terhadap Produk Domestik Bruto dari 57,84 \% menjadi 60,34\% dalam lima tahun terakhir. Serapan tenaga kerjanya juga meningkat dari 96,99\% menjadi 97,22\% pada periode yang sama. Kementerian Perindustrian atau Kemenperin adalah kementerian dalam Pemerintahan Indonesia yang membidangi urusan perindustrian.

Di Indonesia terdapat berbagai jenis UMKM yang bergerak pada industri yang beragam seperti industri fashion, kuliner, konveksi, otomotif, teknologi dan masih banyak lagi. Namun dalam penelitian ini penulis akan berfokus pada UMKM yang bergerak pada bidang industri kuliner. Industri kuliner merupakan sebuah bisnis yang sedang berkembang di Indonesia pada saat ini. Munculnya berbagai makanan yang unik, adanya wisata kuliner dan tren kuliner sebagai gaya hidup masyarakat menjadi bukti bahwa bisnis ini berkembang dengan pesat (Ranto, 2016). Data lain terkait industri kuliner dapat dilihat dari analisis pertumbuhan industri yang dilakukan oleh Kemenperin pada gambar dibawah ini :

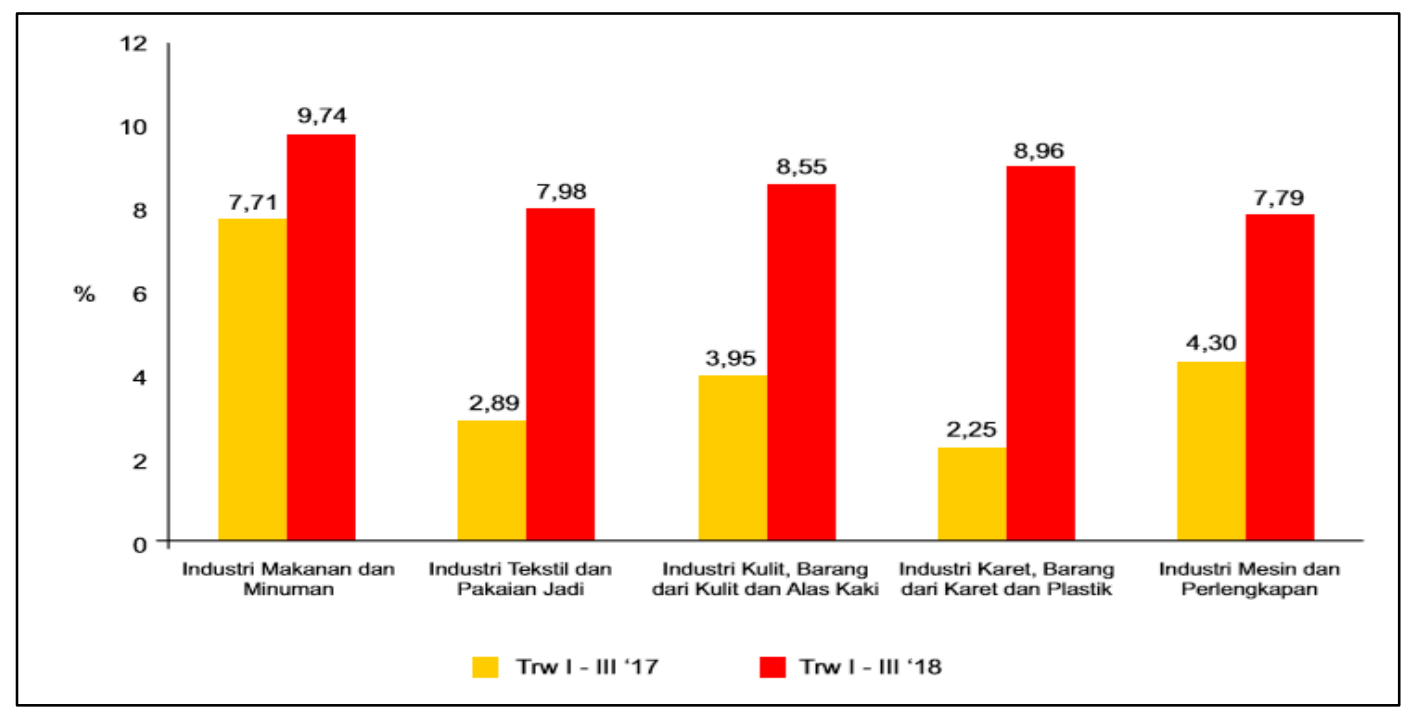




\section{Gambar 1.1.Grafik Pertumbuhan Beberapa Industri yang Mengalami Kenaikan pada Triwulan I - Triwulan III 2018.}

Sumber : Kementerian Perindustrian Edisi IV, 2018.

Dari data analisis pertumbuhan industri yang dilakukan oleh Kemenperin, terdapat beberapa kelompok industri yang mengalami pertumbuhan pada periode I hingga Triwulan III 2018. Pertumbuhan tertinggi dicapai oleh kelompok industri makanan dan minuman yang mencapai pertumbuhan sebesar $9,74 \%$, pertumbuhan ini lebih tinggi dari pertumbuhan sebesar 7,71\% pada tiga triwulan pertama tahun 2017. Menurut Menteri Perindustrian Airlangga Hartarto, mengatakan bahwa pertumbuhan industri makanan dan minuman ini dapat membantu pemerataan ekonomi karena mayoritas pelakunya adalah sektor UMKM.

Menurut Valentine dan Devie (2015), terdapat beberapa alat ataupun teknik yang dapat digunakan perusahaan yang dapat berhubungan dengan konsumen, yaitu customer accounting dan customer orientation.Customer Accounting merupakan salah satu teknik dari strategic management accounting.Strategic management accounting menunjukkan penggunaan dari sistem akuntansi manajemen untuk menyediakan informasi guna mendukung manajer untuk membuat keputusan strategis dan mengendalikan aktivitas organisasi (Cadez dan Guilding, 2008). Customer accounting merupakan bagian dari informasi akuntansi yang dapat memfasilitasi perkembangan dan pelaksanaan dari strategi bisnis. Informasi akuntansi juga berperan dalam proses pengambilan keputusan yang berhubungan dengan perencanaan, tata kelola serta pengendalian, dengan begitu pelaksanan strategi bisnis yang di dukung oleh informasi akuntansi tersebut akan dapat mencapai kinerja organisasi yang di inginkan (Al-Mawali dan Lam, 2016).

Selain customer accounting, ada cara lain yang digunakan oleh suatu organisasi yang berbasis pada konsumen yaitu customer orientation. Customer orientation adalah suatu tipe orientasi organisasi dimana kebutuhan konsumen menjadi dasar bagi suatu orgaisasi untuk merencanakan dan mendesain strateginya. Setelah menggunakan orientasi tersebut, maka sistem infomasi pemasaran akan mampu untuk melacak konsumen sehingga kinerja organisasi (pertumbuhan penjualan, peningkatan pangsa pasar, dan lain-lain) dapat terjamin (Valentine dan Devie, 2015). Kemampuan 
perusahaan dalam memahami dan melayani kebutuhan konsumen memberikan kontribusi pada peningkatan kinerja perusahaan.

Adapun perbedaan dari hasil penelitian sebelumnya menyebabkan penelitian tentang akuntansi manajemen ini masih menarik untuk dilakukan. Dimulai dari penelitian Valentine dan Devie (2015) mengatakan bahwa adanya pengaruh dari customer accounting terhadap organizational performance dan customer orientation memiliki pengaruh terhadap organizational performance. Selanjutnya, penelitian yang dilakukan oleh Holm, Kumar dan Plenborg (2016) mengatakan bahwa kinerja organisasi mengalami peningkatan di dua tahun pertama setelah mengadobsi customer accounting. Penelitian yang dilakukan oleh Rosiana (2017) mengatakan bahwa orientasi pelanggan berpengaruh terhadap kinerja usaha UMK tempe.

Namun, hasil berbeda didapat dalam penelitian yang dilakukan oleh Al-Mawali dan Lam (2016) yang mengatakan bahwa dua informasi customer accounting yaitu lifetime customer profitability analysis (LCPA) dan valuation of customer as assets (VCA) tidak memiliki dampak yang pada kinerja organisasi. Perbedaan juga ditemukan dalam penelitian yang dilakukan oleh Sumiati (2015) yang mengatakanbahwa orientasi pasar dengan salah satu indikator yaitu orientasi pelanggan tidak berpengaruh terhadap kinerja UMKM di Kota Surabaya.

Penelitian ini merupakan replikasi dari penelitian Valentine dan Devie (2015) dengan judul "Pengaruh Customer Accounting sebagai Strategic Management Accounting Techniques dan Customer Orientation terhadap Organizational Performance".Perbedaan penelitian ini dengan penelitian sebelumnya yaitu pada penelitian ini menambah uji secara simultan dan terdapat perbedaan pada sampel penelitian.

Dari penjabaran latar belakang diatas serta perbedaan dari penelitian terdahulu, maka peneliti tertarik untuk melakukan penelitian yang berjudul "Pengaruh Customer Accounting sebagai Strategic Management Accounting Techniques dan Customer Orientation terhadap Kinerja Organisasi”.

\section{Tujuan}

1. Untuk Mengetahui Apakah Customer Accounting sebagai Strategic Management Accounting Techniques Berpengaruh terhadap Kinerja Organisasi.

2. Untuk Mengetahui Apakah Customer Orientation Berpengaruh terhadap Kinerja Organisasi. 
3. Untuk Mengetahui Apakah Customer Accounting sebagai Strategic Management Accounting Techniques dan Customer Orientation Berpengaruh terhadap Kinerja Organisasi.

\section{Sumber Data}

Jenis data yang digunakan dalam penelitian ini adalah data primer, yaitu data yang dibuat langsung oleh peneliti dan diperoleh dari kuesioner yang akan dibagikan kepada para pelaku UMKM di Pekanbaru. 


\section{KAJIAN LITERATUR}

\section{Teori Resource-Based View}

Resource-based view dikembangkan oleh Barney tahun 1991 merupakan salah satu perspektif yang memiliki kontribusi besar pada berbagai riset dan kajian manajemen strategik.Manajemen strategik diterapkan dalam bisnis atau badan usaha agar bisnis atau badan usaha berjalan dengan baik dalam mencapai tujuan yang telah ditetapkan.Dengan manajemen strategik diharapkan kinerja organisasi mengalami peningkatan.Resource-based view membahas mengenai sumber daya yang dimiliki perusahaan dan bagaimana perusahaan tersebut dapat mengelola dan memanfaatkan sumber daya yang dimilikinya. Warnerfelt, menjelaskan bahwa menurut pandangan RBV, perusahaan akan unggul dalam persaingan usaha dan mendapatkan kinerja organisasi yang baik dengan cara memiliki, menguasai dan memanfaatkan asset-asset strategis yang penting yaitu asset berwujud dan asset tidak berwujud (Siregar, 2016).

Asset tidak berwujud memiliki peran penting dalam mencapai tujuan dan strategi perusahaan serta dalam menentukan nilai pasar perusahaan. Salah satu wujud dari peran penting tersebut dapat dilihat dari pengunaan pengetahuan yang menghasilkan inovasi serta sebagai landasan untuk meningkatkan responsivitas terhadap kebutuhan pelanggan dan stakeholders (Ricky, 2015). Dalam pandangan RBV,

perusahaan harus mempunyai keunggulan dalam hal sumber daya dan bisa mengelola sumber daya tersebut menjadi kekuatan untuk membentuk keunggulan bersaing (Andiyanto dan Sufian, 2017).

\section{Kinerja Organisasi}

Kinerja organisasi merupakan kriteria paling penting dalam mengevaluasi organisasi serta tindakan dan lingkungan mereka.Kinerja organisasi memungkinkan peneliti dan manajer untuk mengevaluasi perusahaan dari waktu ke waktu dan membandingkanya dengan para pesaing.Secara umum tujuan suatu perusahaandidirikan adalah untuk menciptakan kekayaan.Untuk mencapai tujuan tersebut, perusahaan harus memiliki produk yang dapat dijual kepada masyarakat (Rudianto, 2013).

Keberhasilan setiap organisasi tercermin dari kinerjanya yang sangat bergantung pada strategi organisasi.Pada akuntansi manajemen strategik termasuk diantaranya mengendalikan biaya sebagai strategi untuk peningkatan kinerjanya. Bentuk analisis 
activity based costing, time driven activity based costing merupakan bagian akuntansi manajemen strategiknya(Azmi, 2018). Dalam hal peningkatan kinerja, Organisasiorganisasi juga harus mengerti bahwa perlu untuk mengukur kinerja organisasi tidak hanya dari segi keuangan saja, namun juga dari tingkat kepuasan konsumen, pengembangan teknologi, dan terciptanya lingkungan untuk mendukung pembelajaran dan pertumbuhan (Valentine dan Devie, 2015). Oleh karena itu, untuk meningkatkan kepuasan berbagai pihak maka perusahaan perlu melakukan perencanaan yang terintegrasi dan terkoordinasi dalam upaya memuaskan berbagai pihak dan tetap selaras dengan strategi perusahaan untuk mencapai visi dan misi yang telah ditetapkan sebelumnya.

Salah satu cara yang dapat dilakukan adalah dengan melakukan perencanaan pengukuran kinerja yang tidak hanya melihat dari aspek keuangan saja namun perusahaan juga harus melihat dari aspek non keuangan agar dapat mengetahui sampai sejauh mana tingkat kepuasan berbagai pihak telah terpenuhi (Nazaruddin, 2015). Balanced Scorecard dapat menjadi salah satu alat pengukuran kinerja strategis bagi suatu organisasi.Kesuksesan jangka panjang dari organisasi ditentukan dari kapabilitas dan kompetensi yang dikembangkannya.

Menurut Kaplan dan Norton (2000) terdapat empat perspektif dalam Balanced Scorecard, yaitu :

1. Perspektif Keuangan

Balanced Scorecard tetap menggunakan perspektif keuangan karena ukuran keuangan sangat penting dalam memberikan ringkasan konsekuensi tindakan ekonomis yang telah diambil.Ukuran kinerja keuangan memberikan petunjuk apakah strategi perusahaan, implementasi dan pelaksanaan nya memberikan kontribusi atau tidak kepada peningkatan laba perusahaan.

2. Perspektif Pelanggan

Dalam pespektif pelanggan, dapat melihat bagaimana organisasi tampil dalam perspektif pelanggan telah menjadi prioritas utama untuk top manajemen.Perhatian kepada pelanggan cenderung dikategorikan menjadi empat yaitu waktu, kualitas, kinerja dan pelayanan, serta biaya.

3. Perspektif Proses Bisnis Internal

Agar suatu perusahaan dapat memenuhi kebutuhan konsumennya, maka dibutuhkan proses, keputusan, dan tindakan dalam perusahaan tersebut. Manajer 
harus fokus pada operasi internal tersebut agar dapat memenuhi kebutuhan konsumen. Dalam hal ini, perusahaan berfokus pada tiga proses bisnis utama yaitu proses inovasi, proses operasi, dan proses layanan purna jual.

4. Perspektif Pembelajaran dan Pertumbuhan.

Perspektif ini mengidentifikasi infrastruktur yang harus dibangun perusahaan dalam menciptakan pertumbuhan dan peningkatan kinerja jangka panjang.Tiga sumber utama pembelajaran dan pertumbuhan perusahaan datang dari manusia, sistem, dan prosedur perusahaan.

\section{Customer Accounting}

Customer Accounting merupakan salah satu teknik dari Strategic Management Accounting.Istilah dari Strategic Management Accounting sendiri pertama kali diungkapkan oleh Simmonds pada tahun 1981 (McManus dan Guilding, 2008). Strategic management accounting merupakan sebuah peran strategis dari akuntansi manajemen dengan menggunakan pendekatan dalam pembiayaan, tata kelola kinerja, dan penilaian investasi strategis (Cadez dan Guilding, 2008). Cadez dan Guilding membagi teknik atau alat strategic management accounting yang disebut strategic management accounting techniques (SMAT) menjadi 5 teknik, yaitu strategic costing; strategic planning, control, and performance management; strategic decision making; competitor accounting; dan customer accounting.

Customer accounting mencakup semua praktik akuntansi dalam hubungannya dengan profit, penjualan, dan present value dari pendapatan yang berhubungan dengan tiap konsumen atau kelompok konsumen (Cadez dan Guilding, 2008). Customer accounting juga didefinisikan sebagai perluasan sebuah konsep penggunaan informasi untuk beberapa alasan strategis organisasi. Menurut Cadez \& Guilding (2008), customer accounting memiliki 3 dimensi yaitu:

\section{Analisis Profitabilitas Pelanggan}

Secara sederhana, Analisis Profitabilitas Pelanggan dapat diartikan sebagai sebuah pendekatan manajemen biaya yang mengidentifikasi biaya dan manfaat melayani pelanggan individu atau kelompok pelanggan untuk meningkatkan profit perusahaan secara keseluruhan.

2. Analisis Profitabilitas Pelanggan Seumur Hidup 
Analisis profitabilitas pelanggan seumur hidup adalah ekspansi atau perpanjangan waktu dari analisa profitabilitas waktu hidup konsumen dimana diperhitungkan pendapatan dan biaya dari tiap konsumen di masa depan.

3. Penilaian Pelanggan Sebagai Aset

Penilaian pelanggan sebagai aset adalah perhitungan dari nilai konsumen terhadap organisasi.Pelanggan, dapat kita katakan sebagai suatu asset yang berharga di dalam perusahaan, karena dengan adanya pelanggan perusahaan dapat memperoleh pasar dan memperoleh profit. Untuk itu, kini banyak perusahaan yang mulai beramairamai meningkatkan kinerja mereka, memperkuat interaksi mereka dengan pelanggan dengan tujuan memberi kan kepuasan kepada pelanggan, sehingga memberikan penilaian yang positif bagi pelanggan terhadap perusahaan.

\section{Customer Orientation}

Menurut Narver dan Slater (1990), customer orientation merupakan salah satu komponen dari market orientation.Istilah market orientation sendiri pertama kali digunakan oleh Kohli dan Jaworski (1990).Mereka menggunakan istilah itu untuk menjelaskan implementasi dari marketing concept.Narver dan Slater (1990) mendefinisikan orientasi pasar sebagai budaya organisasi yang paling efektif dalam menciptakan perilaku penting untuk penciptaan nilai unggul bagi pembeli serta kinerja dalam bisnis. Menurut Kohli dan Jaworski (1993), market orientation adalah pengetahuan seluruh organisasi akan informasi pasar yang berkaitan dengan kebutuhan pelanggan saat ini dan masa depan, penyebaran informasi mengenai antar departemen dan respon dari keseluruhan organisasi akan informasi tersebut.

Customer orientation adalah suatu tipe orientasi organisasi dimana kebutuhan konsumen menjadi dasar bagi suatu organisasi untuk merencanakan dan mendesain strateginya. Perusahaan yang berorientasi kepada pelanggan senantiasa berupaya menggali apa yang dapat disediakan perusahaan dengan membuat barang atau jasa yang terbaik (Rosiana, 2017). Dengan demikian dapat didefinisikan bahwa orientasi pelanggan adalah semua aktivitas yang berkontribusi pada pemahaman perusahaan terhadap kebutuhan para pelanggan sasarannya dan kemampuan perusahaan untuk merancang produk dan jasa yang dapat memuaskan kebutuhan dari para pelanggan tersebut. Menurut Kohli dan Jaworski (1990), Customer Orientation memiliki 3 dimensi yaitu : 


\section{Analisis Pelanggan}

Analisis pelangganmerupakan komponen dari market orientation, dimana analisis pelanggan mengetahui tidak hanya kebutuhan dan preferensi konsumen, namun juga faktor-faktor lain yang mempengaruhi kebutuhan dan preferensi tersebut.

2. Penyebaran Intelegen Pelanggan

Agar perusahaan dapat beradaptasi pada kebutuhan pasar, maka informasi mengenai pasar harus dikomunikasikan, disebarkan, dan mungkin juga diserahkan pada departemen dan orang yang membutuhkannya.Selain itu juga dibutuhkan partisipasi dari semua departemen di organisasi sehingga informasi perlu untuk disebarkan di seluruh organisasi.

3. Respon

Responsiveness merupakan perilaku perusahaan sebagai respon atas intelejen (informasi) yang telah didapatkan dan disebarkan ke dalam organisasi.

\section{Pengembangan Hipotesis}

\section{Hubungan Customer Accounting sebagai Strategic Management Accounting Techniques terhadap Kinerja Organisasi.}

Menurut Resource-Based View Theory, strategi dilakukan dengan mengalokasikan sumber daya kepada kebutuhan pasar pada saat kemampuan perusahaan bersaing tidak mencukupi sehingga akan memberikan hasil yang efektif bagi perusahaan. Sumber daya dan kemampuan perusahaan merupakan hal yang penting dalam strategi tingkat bisnis dan sumber daya bernilai yang dapat mempengaruhi berbagai usaha yang dilakukan perusahaan merupakan hal yang penting dalam strategi tingkat korporasi (Ricky, 2015).

Customer Accounting merupakan salah satu teknik dari strategic management accounting dapat membantu dalam mencapai kinerja organisasi (Cadez dan Guilding, 2008). Hal ini kerena peran utama dari customer accounting yang merupakan bagian dari sistem informasi akuntansi adalah memfasilitasi perkembangan dan pelaksanaan dari strategi bisnis. Informasi akuntansi juga berperan dalam proses pengambilan keputusan yang berhubungan dengan perencanaan, tata kelola, pengarahan, dan pengendalian organisasi. Dengan begitu, maka pelaksanaan strategi bisnis yang didukung oleh informasi akuntansi tersebut akan dapat mencapai kinerja organisasi yang diinginkan (Valentine dan Devie, 2015). 
Menurut penelitian terdahulu diantaranya Lisa Valentine dan Devie (2015) mengatakan bahwa customer accounting berpengaruh terhadap kinerja organisasi, dan penelitian yang dilakukan oleh Holm, Kumar dan Plenborg (2016) mengatakan bahwa bahwa customer accounting berpengaruh terhadap kinerja organisasi. Berdasarkan hasil paparan diatas, maka hipotesis pertama diajukan :

H1: Diduga Customer Accounting sebagai Strategic Management Accounting Techniques berpengaruh terhadap Kinerja Organisasi.

\section{Hubungan Customer Orientation terhadap Kinerja Organisasi.}

Resource-Based View Theory dapat diterapkan untuk mejelaskan berbagai variasi kinerja organisasi bisnis. Menurut pandangan RBV asset berwujud dan tidak berwujud, kapabilitas, proses dan prosedur organisasi menentukan kinerja organisasi (Atmana, 2014).

Menurut Narver dan Salter (1990) Customer orientation merupakan salah satu sumber daya perusahaan.Customer orientation merupakan bentuk dari sumber daya intangible berupa budaya organisasi untuk menciptakan nilai lebih kepada pelanggan dan dapat meningkatkan kinerja bisnis.Dengan demikian dapat didefinisikan bahwa orientasi pelanggan adalah semua aktivitas yang berkontribusi pada pemahaman perusahaan terhadap kebutuhan dan preferensi para pelanggan sasarannya dan kemampuan perusahaan untuk merancang produk dan jasa yang dapat memuaskan kebutuhan dan preferensi dari para pelanggan. Orientasi pelanggan yang baik akan memberikan kontribusi pada peningkatan kinerja perusahaan (Valentine dan Devie, 2015).

Menurut penelitian terdahulu diantaranya Rosiana (2017) dan Daud (2016) mengatakan bahwa customer orientation berpengaruh terhadap kinerja organisasi. Berdasarkan hasil paparan diatas, maka hipotesis kedua diajukan:

H2 : Diduga Customer Orientation berpengaruh terhadap Kinerja Organisasi.

\section{Hubungan Customer Accounting sebagai Strategic Management Accounting Techniques dan Customer Orientation terhadap Kinerja Organisasi.}

Menurut Resource-Based View Theory, strategi dilakukan dengan mengalokasikan sumber daya kepada kebutuhan pasar pada saat kemampuan perusahaan bersaing tidak mencukupi sehingga akan memberikan hasil yang efektif bagi perusahaan (Ricky, 2015).Menurut Valentine dan Devie (2015) mengatakan bahwa perusahaan dapat 
menerapkancustomer accounting dan customer orientation agar kinerja organisasi mengalami peningkatan terutama dalam hal customer perspective yaitu menurunya keluhan pelanggan dan meningkatnya reputasi perusahaan. Perusahaan juga harus dapat mengomunikasikan informasi mengenai pengalaman konsumen diseluruh fungsi bisnis agar setiap orang dalam organisasi berkontribusi dalam menciptakan nilai kepada pelanggan.

Menurut penelitian terdahulu diantaranya Valentine dan Devie (2015), Kumar dan Plenborg (2016), Rosiana (2017) dan Daud (2016) mengatakan bahwa customer accounting dan customer orientation berpengaruh terhadap kinerja organisasi. Berdasarkan hasil paparan diatas, maka hipotesis ketiga diajukan :

H3 : Diduga Customer Accounting sebagai Strategic Management Accounting Techniques dan Customer Orientation berpengaruh terhadap Kinerja Organisasi.

\section{METODE PENELITIAN}

\section{Jenis Penelitian}

Penelitian ini menggunakan metode kuantitatif, yakni penelitian yang berlandaskan pada filsafat positivisme, digunakan untuk meneliti pada populasi atau sampel tertentu, teknik pengambilan sampel pada umumnya dilakukan secara random, pengumpulan data menggunakan instrumen penelitian, analisis data bersifat kuantitatif dengan tujuan untuk menguji hipotesis yang telah ditetapkan (Sugiyono, 2010).

\section{Populasi dan Sampel}

Populasi adalah wilayah generalisasi yang terdiri atas obyek/subyek yang mempunyai kualitas dan karakteristik tertentu yang ditetapkan oleh peneliti untuk dipelajari dan kemudian ditarik kesimpulannya (Sugiyono, 2010). Populasi dalam penelitian ini adalah Usaha Mikro Kecil Menengah (UMKM) di Kota Pekanbaru yang bergerak di bidang usaha kuliner yang terdaftar Online di Portal $\underline{w w w . u k m r i a u . c o m}$ dengan jumlah populasi sebanyak 162 UMKM di bidang kuliner yang ada di kota Pekanbaru. Alasan pemilihan sampel UMKM dikarenakan UMKM cukup kuat dalam menahan gejolak krisis ekonomi (Surenggono dan Djamilah, 2016) dan eksistensinya mendominasi terhadap perekonomian bangsa. Adapun alasan pemilihan UMKM yang terdaftar Online di Portal www.ukmriau.comdikarenakan UMKM yang memiliki akses online dan mengembangkan kemampuan e-commerce nya biasanya akan 
menikmatikeuntungan bisnis yang lebih baik dari segi pendapatan, kesempatan kerja, inovasi dan daya saing (Wardhana, 2017).

Dalam penelitian kuantitatif sampel adalah bagian dari jumlah dan karakteristik yang dimiliki oleh populasi tersebut. Bila populasi besar, dan peneliti tidak mungkinmempelajari semua yang ada pada populasi, misalnya karena keterbatasan dana, tenaga dan waktu, maka peneliti dapat menggunakan sampel yang diambil dari populasi itu. Dalam mengambil sampel dibutuhkan Teknik Sampling yaitu merupakan teknik pengambilan sampel untuk menentukan sampel yang akan digunakan dalam penelitian (Sugiyono, 2010).

Pengambilan sampel dalam penelitian ini menggunakan Purposive Sampling, yaitu pengambilan sampel dengan pertimbangan atau kriteria-kriteria tertentu. Kriteria untuk mengambil sampel dalam penelitian ini adalah :

1. UMKM bidang kuliner yang terdaftar secara online di portal www.ukmriau.com.

2. Merupakan usaha yang memproduksi olahan makanan.

3. Lamanya usaha berdiri minimal 2 tahun, karena dianggap para pelaku usaha ini telah mampu bertahan dan menjalankan usahanya dengan baik (Megawati, 2017).

Berdasarkan kriteria diatas, peneliti telah menetapkan jumlah UMKM yang memiliki kriteria untuk dijadikan sampel sebanyak 85 UMKM.

\section{Jenis dan Sumber Data}

Jenis data yang digunakan dalam penelitian ini adalah data primer, yaitu data yang dibuat langsung oleh peneliti dan diperoleh dari kuesioner yang akan dibagikan kepada para pelaku UMKM di Pekanbaru.

\section{Teknik Pengumpulan Data}

Teknik pengumpulan data yang digunakan dalam penelitian ini adalah melalui penyebaran kuesioner.Pertanyaan-pertanyaan diukur dengan menggunakan Skala Ordinal dengan menggunakan Skala Likert.Skala Likert digunakan untuk mengukur sikap, pendapat, dan persepsi seseorang atau sekelompok orang tentang fenomena sosial (Sugiyono, 2010). Dalam kuesioner yang digunakan peneliti, setiap pertanyaan terdiri dari 5 (Lima) Kategori Jawaban, yaitu :

$\begin{array}{llll}\text { Sangat Setuju (SS) } & =5 & \text { Tidak Setuju (TS) } & =2 \\ \text { Setuju (S) } & =4 & \text { Sangat Tidak Setuju (STS) }=1 \\ \text { Cukup Setuju (CS) } & =3 & \end{array}$




\section{Variabel Penelitian}

Variabel penelitian pada dasarnya adalah segala sesuatu yang berbentuk apa saja yang ditetapkan oleh peneliti untuk dipelajari sehingga diperoleh informasi tentang hal tersebut, kemudian ditarik kesimpulannya (Sugiyono, 2010). Dalam penelitian ini terdapat 2 (dua) variabel, yaitu :

a. Variabel Dependen

Variabel dependen dalam bahasa Indonesia disebut sebagai variabel terikat. Variabel terikat merupakan variabel yang dipengaruhi atau yang menjadi akibat karena adanya variabel bebas. Variabel dependen nilainya akan berubah jika variabel yang mempengaruhinya berubah (Sugiyono, 2010). Variabel dependen dalam penelitian ini adalah Kinerja Organisasi (Y).

b. Variabel Independen.

Variabel independen dalam bahasa Indonesia disebut sebagai variabel bebas. Variabel bebas adalah variabel yang mempengaruhi variabel dependen, baik yang pengaruhnya positif maupun negatif (Sugiyono, 2010).Variabel independen dalam penelitian ini adalah Customer Accounting ( $\left.\mathrm{X}_{1}\right)$ dan Customer Orientation ( $\left.\mathrm{X}_{2}\right)$.

\section{Definisi Operasional Variabel}

\section{Variabel Dependen}

\section{Kinerja Organisasi (Y)}

Kinerja organisasi merupakan kriteria paling penting dalam mengevaluasi organisasi serta tindakan dan lingkungan mereka.Organisasi-organisasi juga harus mengerti bahwa perlu untuk mengukur kinerja organisasi tidak hanya dari segi keuangan saja, namun juga dari tingkat kepuasan konsumen, pengembanganteknologi, dan terciptanya lingkungan untuk mendukung pembelajaran dan pertumbuhan.Adapun indikator yang dapat digunakan untuk mengukur kinerja organisasi yaitu dengan menggunakan Balanced Scorecard. Menurut Kaplan dan Norton (2000) terdapat empat perspektif dalam Balanced Scorecard, yaitu:

1. Perspektif Keuangan

2. Perspektif Pelanggan

3. Perspektif Proses Bisnis Internal

4. Perspektif Pembelajaran dan Pertumbuhan 


\section{Variabel Independen}

\section{Customer Accounting $\left(\mathrm{X}_{1}\right)$}

Customer Accounting merupakan bagian dari sistem informasi akuntansi yang memfasilitasi perkembangan dan pelaksanaan dari strategi bisnis. Informasi akuntansi juga berperan dalam proses pengambilan keputusan yang berhubungan dengan perencanaan, tata kelola, pengarahan, dan pengendalian organisasi (Valentine dan Devie, 2015). Terdapat 3 indikator yang dapat digunakan untuk mengukur Customer Accounting yang diadopsi dari penelitian Cadez dan Guilding (2008) yaitu :

1. Analisis Profitabilitas Pelanggan

2. Analisis Profitabilitas Pelanggan Seumur Hidup

3. Penilaian Pelanggan Sebagai Aset

\section{Customer Orientation $\left(\mathrm{X}_{2}\right)$}

Menurut Narver dan Slater (1990), customer orientation merupakan salah satu komponen dari market orientation. Customer orientation adalah suatu tipe orientasi organisasi dimana kebutuhan konsumen menjadi dasar bagi suatu organisasi untuk merencanakan dan mendesain strateginya (Valentine dan Devie, 2015). Menurut Kohli dan Jaworski (1990), terdapat 3 indikator yang dapat digunakan untuk mengukur Customer Orientation, yaitu :

1. Analisis Pelanggan

2. Penyebaran Pengetahuan Pelanggan

3. Respon

\section{Teknik Analisis Data}

Analisis data penelitian ini akan dimulai dengan melakukan uji validitas dan reliabilitas pada kuesioner yang telah didapatkan dari responden yang telah menjawab pertanyaan-pertanyaan yang terdapat di dalam kuesioner. Dari hasil kuesioner yang didapatkan akan dianalisis menggunakan pengolahan data dengan komputer melalui program SPSS (Statistical Product and Service Solution) versi 22.

\section{Uji Kualitas Data}

Uji kualitas data digunakan untuk mendapatkan kepastian apakah hasil yang ada dapat menggambarkan keadaan yang sebenarnya.Uji kualitas data terdiri dari uji validitas dan uji reliabilitas (Sugiyono, 2010).

1. Uji Validitas 
Uji validitas merupakan uji yang digunakan untuk mengukur valid atau tidaknya suatu instrumen penelitian. Valid berarti instrumen tersebut dapat digunakan untuk mengukur apa yang seharusnya diukur (Sugiyono, 2010).

2. Uji Reliabilitas

Uji reliabilitas merupakan uji yang digunakan untuk mengetahui seberapa jauh hasil pengukuran tetap konsisten apabila dilakukan pengukuran dua kali atau lebih terhadap gejala yang sama dengan menggunakan alat pengukuran yang sama. Untuk menguji reliabilitas, suatu kuesioner dikatakan reliabel jika nilai Cronbach's Alpha> 0,60 (Sugiyono, 2010).

\section{Uji Asumsi Klasik}

Uji asumsi klasik adalah analisis yang dilakukan untuk menilai apakah di dalam sebuah model regresi linear ordinary least square (OLS) terdapat masalahmasalahasumsi klasik.Uji asumsi klasik yang digunakan dalam penelitian ini adalah uji normalitas, uji heterokedastisitas, dan uji multikolonieritas.

a. Uji Normalitas

Uji normalitas bertujuan untuk mengetahui normal atau tidaknya suatu distribusi data. Salah satu cara untuk melihat normalitas residual adalah dengan uji statistik non parametik Kolmogorov-SmirnovTest dengan kriteria pengujian uji (Ghozali, 2011):

1. Jika nilai signifikansi $>0,05$, maka data berdistribusi secara normal.

2. Jika nilai signifikansi $<0,05$, maka data tidak berdistribusi secara normal.

b. Uji Multikolinieritas

Uji multikolinieritas bertujuan untuk menguji apakah model regresi ditemukan adanya korelasi antar variabel bebas (independen).Model regresi yang baik seharusnya tidak terjadi korelasi di antara variabel independen.Jika variabel independen saling berkorelasi, maka variabel-variabel ini tidak orthogonal. Variabel orthogonal adalah variabel independen yang nilai korelasi antar sesama variabel independen sama dengan nol. Untuk mendeteksi ada atau tidaknya multikolinieritas di dalam model regresi dapat dilihat dari (Ghozali, 2011):

1. Nilai Tolerance/lawannya

2. Variance Inflation Factor (VIF) 
Nilai tolerance yang rendah sama dengan nilai VIF tertinggi (karena VIF = 1/Tolerance), nilai cut off yang umum dipakai untuk menunjukkan adanya multikolinieritas, yaitu:

1. Jika nilai VIF < 10 maka tidak terjadi gejala multikolinieritas diantara variabel bebas.

2. Jika nilai VIF > 10 maka terjadi gejala multikolinieritas diantara variabel bebas.

c. Uji Heteroskedastisitas

Uji heteroskedastisitas bertujuan untuk menguji apakah dalam model regresi terjadi ketidaksamaan variance dari residual satu pengamatan ke pengamatan yang lain. Jika variance dari residual satu pengamatan ke pengamatan lain tetap, maka disebut homoskedastisitas dan jika berbeda disebut heteroskedastisitas.

Model regresi yang baik adalah yang homoskedastisitas atau tidak terjadi heteroskedastisitas. Apabila hasil uji diatas level signifikan ( $r>0,05)$ berarti tidak terjadi heteroskedastisitas dan sebaliknya apabila level dibawah signifikan $(r<0,05)$ berarti terjadi heteroskedastisitas (Ghozali, 2011).

\section{Uji Koefisien Determinasi}

Koefisien determinasi $\left(\mathrm{R}^{2}\right)$ mengukur seberapa jauh kemampuan model dalam menerangkan variasi variabel dependen.Nilai $\mathrm{R}^{2}$ mempunyai interval antara 0 sampai 1 $\left(0 \leq R^{2} \leq 1\right)$.Semakin besar $R^{2}$ (mendekati 1$)$, semakin baik hasil untuk model regresi tersebut dan semakin mendekati 0, maka variabel independen secara keseluruhan tidak dapat menjelaskan variabel dependen.Nilai $\mathrm{R}^{2}$ yang kecil berarti kemampuan variabelvariabel independen dalam menjelaskan variasi variabel dependen amat terbatas.Nilai yang mendekati satu berarti variabel-variabel independen memberikan hampir semua informasi yang dibutuhkan untuk memprediksi variasi variabel dependen (Ghozali, 2011).

\section{Analisis Regresi Berganda}

Analisis yang akan digunakan dalam penelitian ini adalah analisis regresi berganda, yakni cara yang digunakan untuk melihat hubungan antara dua atau lebih variabel independen terhadap satu variabel dependen. Analisis data dilakukan dengan bantuan program aplikasi SPSS. Berikut persamaan regresi dalam penelitian ini :

$Y=\alpha+\beta 1 . \mathrm{X}_{1}+\beta 2 . \mathrm{X}_{2}+\mathrm{e}$

Keterangan: 


$$
\begin{array}{ll}
\mathrm{Y} & =\text { Kinerja Organisasi } \\
\alpha & =\text { Konstanta } \\
\beta & =\text { Koefisien regresi } \\
\mathrm{X}_{1} & =\text { Customer Accounting } \\
\mathrm{X}_{2} & =\text { Customer Orientation } \\
\mathrm{e} & =\text { error }
\end{array}
$$

\section{Uji Hipotesis}

Pengujian hipotesis dilakukan dengan menggunakan alat analisis regresi berganda yang dimaksudkan untuk mengetahui hubungan antara dua atau lebih variabel independen terhadap satu variabel dependen. Pengujian hipotesis ini melalui beberapa pengujian, yakni:

\section{1) Uji Statistik $t$}

Uji statistik $\mathrm{t}$ menunjukkan seberapa jauh pengaruh satu variabel penjelas dan independen secara individu dalam menerangkan variasi variabel dependen.Apakah variabel independen berpengaruh secara nyata atau tidak (Ghozali, 2011). Dasar pengambilan keputusan yaitu:

Jika probabilitas $>0,05$ maka model ditolak

Jika probabilitas < 0,05 maka model diterima

\section{2) Uji Statistik F}

Uji statistik F menunjukkan apakah semua variabel independen yang dimasukkan dalam model mempunyai pengaruh secara bersama-sama terhadap variabel dependen (Ghozali, 2011). Dalam membandingkan probabilitas (pada tabel anova tertulis Sig) dengan taraf nyata kurang dari 0,05.

Jika probabilitas $>0,05$ maka model ditolak Jika probabilitas $<0,05$ maka model diterima 


\section{PEMBAHASAN}

\section{Hasil Penelitian}

\section{Gambaran Umum Objek Penelitian}

Tabel 4.1 Jumlah Kuesioner

\begin{tabular}{|l|c|c|}
\hline \multicolumn{1}{|c|}{ Penyebaran Kuesioner } & Total & Persentase \\
\hline Kuesioner Dibagikan & 85 & $100 \%$ \\
\hline Kuesioner Kembali & 40 & $47 \%$ \\
\hline Kuesioner Tidak Kembali & 45 & $53 \%$ \\
\hline Kuesioner Tidak Lengkap & - & $0 \%$ \\
\hline Kuesioner Dapat Digunakan & 40 & $100 \%$ \\
\hline
\end{tabular}

\section{Sumber : Data diolah, 2019}

Dari Tabel 4.1 dilihat bahwa jumlah kuesioner yang tidak kembali sebanyak 45 dengan tingkat persentase 53\%, sedangkan jumlah kuesioner yang kembali sebanyak 40 dengan persentase $47 \%$ dan kuesioner yang kembali seluruhnya layak digunakan dalam penelitian ini.

Tabel 4.2 Profil Responden Berdasarkan Jenis Kelamin

\begin{tabular}{|c|l|c|c|}
\hline No & \multicolumn{1}{|c|}{ Penyebaran Kuesioner } & Total & Persentase \\
\hline 1 & Laki-laki & 27 & $67,5 \%$ \\
\hline 2 & Perempuan & 13 & $32,5 \%$ \\
\hline & Jumlah & 40 & $100 \%$ \\
\hline
\end{tabular}

\section{Sumber : Data diolah, 2019}

Adapun gambaran umum profil seluruh responden berdasarkan jenis kelamin dalam penelitian ini dapat dilihat pada tabel 4.2 diatas yaitu lebih dominan laki-laki sebesar $67,5 \%$ sedangkan perempuan hanya sebesar $32,5 \%$.

Tabel 4.3 Profil Responden Berdasarkan Usia

\begin{tabular}{|c|c|c|c|}
\hline No & Usia & Jumlah & Persentase \\
\hline 1 & $20-30$ Tahun & 2 & $5 \%$ \\
\hline
\end{tabular}




\begin{tabular}{|c|l|c|c|}
\hline 2 & $31-40$ Tahun & 24 & $60 \%$ \\
\hline 3 & $41-50$ Tahun & 9 & $22,5 \%$ \\
\hline 4 & -60 Tahun & 1 & $2,5 \%$ \\
\hline 5 & $>60$ Tahun & 4 & $10 \%$ \\
\hline & Jumlah & 40 & $100 \%$ \\
\hline
\end{tabular}

\section{Sumber : Data diolah, 2019}

Dari Tabel 4.3 usaha kuliner dilakukan oleh pelaku usaha dengan usia 20-30 tahun sebanyak 5\% selanjutnya antara usia 31-40 tahun sebanyak 60\%, usia antara 41-50 tahun sebanyak 22,5\%, usia antara 51-60 tahun sebanyak 2,5\% dan usia diatas 60 tahun sebanyak 10\%. Didalam analisis demografi, struktur usia seseorang dibedakan menjadi tiga kelompok, yaitu (a) kelompok umur muda, dibawah 15 tahun; (b) kelompok umur produktif, usia 15-64 tahun; (c) kelompok umur tua, 65 tahun keatas (Rosiana, 2017). Berdasarkan pengelompokan itu, maka pelaku usaha kuliner dilakukan oleh kelompok umur produktif.

Badan Pusat Statistik (BPS) mengelompokkan menjadi dua kelompok umur produktif, yaitu usia sangat produktif antara 15-49 tahun dan usia produktif antara 5064 tahun (Rosiana, 2017). Dengan demikian pelaku usaha kuliner banyak dilakukan oleh usia sangat produktif yaitu sebesar 87,5\%, dan usia produktif sebesar 12,5\%.

Tabel 4.4 Profil Responden Berdasarkan Tingkat Pendidikan

\begin{tabular}{|c|l|c|c|}
\hline No & Tingkat Pendidikan & Jumlah & Persentase \\
\hline 1 & SMP & 2 & $5 \%$ \\
\hline 2 & SMA & 25 & $62,5 \%$ \\
\hline 3 & D3 & 5 & $12,5 \%$ \\
\hline 4 & S1 & 7 & $17,5 \%$ \\
\hline 5 & S2 & 1 & $2,5 \%$ \\
\hline & & 40 & $100 \%$ \\
\hline
\end{tabular}

\section{Sumber : Data diolah, 2019}


Dari Tabel 4.4 dapat dilihat bahwa sebanyak 5\% pelaku usaha kuliner dengan tingkat pendidikan SMP, 62,5\% pelaku usaha kuliner dengan tingkat pendidikan SMA, $12,5 \%$ pelaku usaha kuliner dengan tingkat pendidikan D3, 17,5\% pelaku usaha kuliner dengan tingkat pendidikan S1 dan 2,5\% dengan tingkat pendidikan S2.

\section{Uji Statistik Deskriptif}

Gambaran-gambaran mengenai variabel penelitian yaitu Customer Accounting, Customer Orientation dan Kinerja Organisasi dapat disajikan dalam tabel descriptive statistics yang menunjukkan angka minimum, maksimum, mean, dan standar deviasi yang dapat dilihat pada tabel dibawah ini:

Tabel 4.5 Hasil Uji Statistik Deskriptif

\begin{tabular}{|l|c|c|c|c|l|c|}
\hline \multicolumn{7}{|c|}{ Descriptive Statistics } \\
\hline & $\mathrm{N}$ & Min & Max & Sum & Mean & Std. Deviation \\
\hline CA (X1) & 40 & 29 & 40 & 1336 & 33.40 & 3.053 \\
\hline CO (X2) & 40 & 28 & 38 & 1341 & 33.53 & 2.511 \\
\hline KO (Y) & 40 & 27 & 40 & 1354 & 33.85 & 2.788 \\
\hline Valid N (listwise) & 40 & & & & & \\
\hline
\end{tabular}

\section{Sumber : Data diolah, 2019}

Dari Tabel 4.5 diatas memperlihatkan deskripsi variabel-variabel dalam penelitian ini secara statistik.Minimum (Min) adalah nilai yang terendah dari totalnilai pertanyaan setiap variabel, sedangkan Maximum (Max) adalah nilai tertinggi dari total nilai pertanyaan setiap variabel.

Dapat dilihat diatas bahwa variabel customer accounting memperlihatkan bahwa nilai minimum dari total pertanyaan variabel adalah 29 , untuk nilai maximum sebesar 40, rata-rata dari total pertanyaan adalah 33,40 dengan standar deviasi 3,053. Variabel customer orientation memperlihatkan bahwa nilai minimum dari total pertanyaan variabel adalah 28, untuk nilai maximum sebesar 38, rata-rata dari total pertanyaan adalah 33,53 dengan standar deviasi 2,511. Variabel kinerja organisasi memperlihatkan bahwa nilai minimum dari total pertanyaan variabel adalah 27 , untuk nilai maximum sebesar 40, rata-rata dari total pertanyaan adalah 33,85 dengan standar deviasi 2,788.

\section{Kualitas Data}




\section{Uji Validitas Data}

Tabel 4.6 Hasil Uji Validitas

\begin{tabular}{|c|c|c|c|c|}
\hline \multicolumn{5}{|c|}{ Customer Accounting (X1) } \\
\hline No & Item & $\begin{array}{l}\text { Person Corelation } \\
\text { (r hitung) }\end{array}$ & $\begin{array}{c}\text { Koefisien Korelasi } \\
\text { (r tabel) }\end{array}$ & Ket \\
\hline 1 & $\mathrm{X} 1.1$ & 0,577 & 0,3120 & Valid \\
\hline 2 & $\mathrm{X} 1.2$ & 0,689 & 0,3120 & Valid \\
\hline 3 & $\mathrm{X} 1.3$ & 0,666 & 0,3120 & Valid \\
\hline 4 & $\mathrm{X} 1.4$ & 0,684 & 0,3120 & Valid \\
\hline 5 & $\mathrm{X} 1.5$ & 0,594 & 0,3120 & Valid \\
\hline 6 & $\mathrm{X} 1.6$ & 0,695 & 0,3120 & Valid \\
\hline 7 & $\mathrm{X} 1.7$ & 0,619 & 0,3120 & Valid \\
\hline 8 & $\mathrm{X} 1.8$ & 0,591 & 0,3120 & Valid \\
\hline \multicolumn{5}{|c|}{ Customer Orientation (X2) } \\
\hline No & Item & $\begin{array}{l}\text { Person Corelation } \\
\text { (r hitung) }\end{array}$ & $\begin{array}{l}\text { Koefisien Korelasi } \\
\text { (r tabel) }\end{array}$ & Ket \\
\hline 1 & $\mathrm{X} 2.1$ & 0,691 & 0,3120 & Valid \\
\hline 2 & $\mathrm{X} 2.2$ & 0,717 & 0,3120 & Valid \\
\hline 3 & $\mathrm{X} 2.3$ & 0,406 & 0,3120 & Valid \\
\hline 4 & $\mathrm{X} 2.4$ & 0,469 & 0,3120 & Valid \\
\hline 5 & $\mathrm{X} 2.5$ & 0,702 & 0,3120 & Valid \\
\hline 6 & $\mathrm{X} 2.6$ & 0,615 & 0,3120 & Valid \\
\hline 7 & $\mathrm{X} 2.7$ & 0,508 & 0,3120 & Valid \\
\hline 8 & $\mathrm{X} 2.8$ & 0,526 & 0,3120 & Valid \\
\hline \multicolumn{5}{|c|}{ Kinerja Organisasi (Y) } \\
\hline No & Item & $\begin{array}{l}\text { Person Corelation } \\
\text { (r hitung) }\end{array}$ & $\begin{array}{c}\text { Koefisien Korelasi } \\
\text { ( } \mathrm{r} \text { tabel) }\end{array}$ & Ket \\
\hline 1 & Y.1 & 0,578 & 0,3120 & Valid \\
\hline 2 & Y.2 & 0,586 & 0,3120 & Valid \\
\hline 3 & Y.3 & 0,708 & 0,3120 & Valid \\
\hline 4 & Y.4 & 0,445 & 0,3120 & Valid \\
\hline 5 & Y.5 & 0,520 & 0,3120 & Valid \\
\hline
\end{tabular}




\begin{tabular}{|c|c|c|c|c|}
\hline 6 & Y.6 & 0,567 & 0,3120 & Valid \\
\hline 7 & Y.7 & 0,640 & 0,3120 & Valid \\
\hline 8 & Y.8 & 0,769 & 0,3120 & Valid \\
\hline
\end{tabular}

\section{Sumber : Data diolah, 2019.}

Dari tabel 4.6 diatas dapat diketahui bahwa masing-masing item pertanyaan valid, hal ini dapat diidentifikasi berdasarkan, apabila nilai korelasi besar dari $r$ tabel maka data tersebut valid. Data diatas menunjukkan nilai korelasi lebih besar dari r tabel, nilai $r$ tabel yaitu degree of freedom (df) $=n-2=40-2=38$ dengan alpha 0,05 didapat $r$ tabel 0,3120. Dengan demikian item pertanyaan yang digunakan dinyatakan valid dan bisa digunakan.

\section{Uji Reliabilitas}

Uji reliabilitas digunakan untuk melihat apakah hasil yang diperoleh melalui instrument tersebut konsisten dan dapat dipercaya. Adapun hasil uji reliabilitas yang diperoleh dalam penelitian ini adalah sebagai berikut :

Tabel 4.7 Hasil Uji Reliabilitas

\begin{tabular}{|l|c|c|c|}
\hline \multicolumn{1}{|c|}{ Variabel } & $\begin{array}{c}\text { Cronbach } \\
\text { Alpha }\end{array}$ & Nilai Kritis & Ket \\
\hline $\begin{array}{l}\text { Customer } \\
\text { Accounting }\end{array}$ & 0,792 & 0,60 & Reliabel \\
\hline $\begin{array}{l}\text { Customer } \\
\text { Orientation }\end{array}$ & 0,711 & 0,60 & Reliabel \\
\hline Kinerja Organisasi & 0,737 & 0,60 & Reliabel \\
\hline
\end{tabular}

\section{Sumber : Data diolah, 2019.}

Dari tabel 4.7 diatas menunjukkan bahwa nilai Cronbach alpha besar dari 0,60. Reliabilitas kurang dari 0,60 adalah kurang baik, sedangkan diatas 0,60 maka dapat diterima. Hal ini menunjukkan bahwa indikator setiap variabel dapat dikatakan reliabel.

\section{Uji Asumsi Klasik}

\section{Uji Normalitas}

Uji normalitas bertujuan untuk menguji apakah dalam model regresi, variabel pengganggu atau residual memiliki distribusi normal. Adapun uji normalitas adalah :

Tabel 4.8 Hasil Uji Normalitas One-Sample Kolmogorov-Smirnov Test 


\begin{tabular}{|l|l|r|}
\hline \multicolumn{2}{|l|}{} & Unstandardized Residual \\
\hline Normal Parameters & \\
& Mean & .0000000 \\
\cline { 2 - 3 } & Std. Deviation & 1.66610046 \\
\hline Most Extreme Differences & Absolute & .073 \\
\cline { 2 - 3 } & Positive & .054 \\
\cline { 2 - 3 } & Negative & .073 \\
\hline Test Statistic & .073 \\
\hline Asymp. Sig. (2-tailed) & .200 \\
\hline S. Test distribution is normal & \\
\hline Sumber : Data diolah, 2019 & \\
\hline
\end{tabular}

Berdasarkan uji normalitas dengan Kolmogrov-Smirnov Test diperoleh nilai Kolmogorov-Smirnov $Z$ sebesar 0,073 dan Asymp.sig 0,200 lebih besar dari 0,05, maka dapat disimpulkan bahwa data terdistribusi normal. Berdasarkan uji asumsi klasik dan hasil output menunjukkan bahwa data tersebut memenuhi persyaratan untuk melakukan uji regresi linear berganda.

\section{Uji Multikolinearitas}

Uji multikolinearitas bertujuan untuk menguji apakah dalam suatu model regresi ditemukan adanya korelasi antara variabel independen atau tidak. Uji multikolinearitas dapat dilihat dari Variance Inflation Factor (VIF) dan tolerance value (nilai toleransi). Multikolinearitas terjadi jika nilai toleransi $<0,10$ atau nilai VIF $>10$.

Tabel 4.9 Hasil Uji Multikolinearitas

\begin{tabular}{|c|c|c|c|}
\hline \multicolumn{4}{|c|}{ Coefficients $^{\underline{\mathbf{a}}}$} \\
\hline \multirow[b]{2}{*}{ Model } & & \multicolumn{2}{|c|}{ Collinearity Statistics } \\
\hline & & Tolerance & VIF \\
\hline \multirow[t]{3}{*}{1} & (Constant) & & \\
\hline & Customer Accounting & .602 & 1.660 \\
\hline & Customer Orientation & .602 & 1.660 \\
\hline
\end{tabular}

\section{Sumber : Data diolah, 2019.}

Tabel 4.9 menunjukkan hasil uji multikolinearitas yang dilakukan dalam penelitian ini yaitu dengan melihat dengan nilai tolerance dan VIF. Terlihat bahwa nilai tolerance tidak ada yang lebih kecil dari 0,10. Sedangkan VIF yang tertera pada tabel yang 
menunjukkan nilai lebih kecil dari 10.Jadi, dapat disimpulkan bahwa tidak terdapat multikolinearitas antara variabel independen dalam model regresi.

\section{Uji Heteroskedastisitas}

Uji heteroskedastisitas bertujuan untuk menguji apakah dalam model regresi terjadi ketidaksamaan variance dari residual satu pengamatan ke pengamatan yang lain (Ghozali, 2011).Model regresi yang baik adalah yang homoskedastisitas atau tidak terjadi heteroskedastisitas. Cara memprediksi ada atau tidaknya heteroskedastisitas pada suatu model dapat dilihat dengan pola gambar scatterplot, apabila titik-titik menyebar secara acak baik dibagian atas angka nol atau dibagian bawah angka nol dari sumbu vertikal atau sumbu Y dapat disimpulkan bahwa tidak terjadi heteroskedastisitas dalam model regresi. Hasil pengujian heteroskedastisitas dapat ditunjukkan pada gambar berikut :

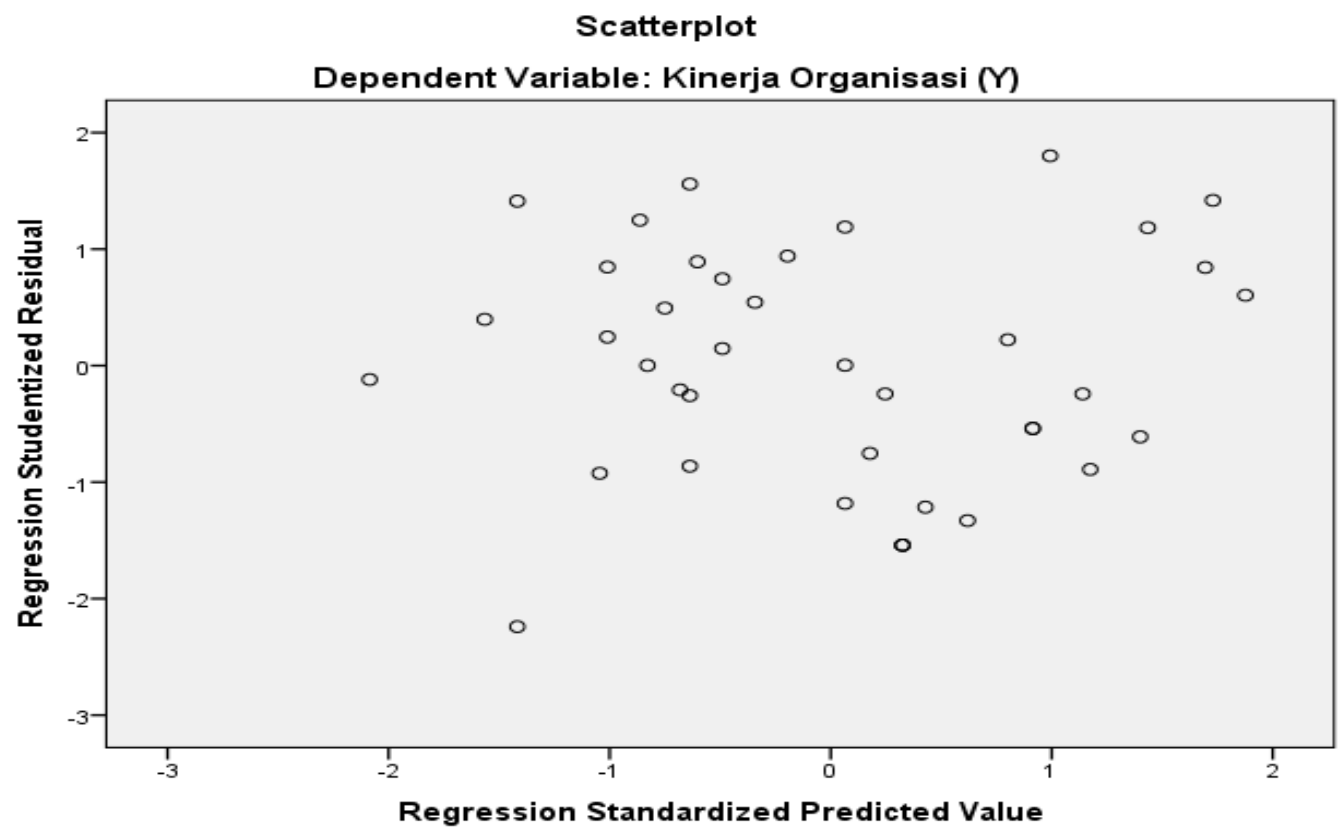

Gambar 4.1 Hasil Uji Heteroskedastisitas

\section{Sumber : Data diolah, 2019.}

Dari gambar 4.1 yang dihasilkan dari uji heteroskedastisitas menunjukkan bahwa titik-titik tidak membentuk pola tertentu atau tidak ada pola yang jelas serta titik-titik menyebar diatas dan dibawah angka 0 (nol) pada sumbu Y, maka dapat disimpulkan bahwa tidak terjadi heteroskedastisitas. Analisis dengan grafik plot tidak dapat sepenuhnya mendeteksi ada tidaknya heteroskedastisitas. Untuk itu diperlukan uji statistik yang dapat menjamin keakuratan hasil. 
Dalam penelitian ini, pendeteksian heteroskedastisitas juga menggunakan uji Glejser. Analisis dapat dilakukan yaitu dengan melihat hasil signifikansi variabel, jika menunjukkan angka diatas 0,05 maka tidak terjadi heteroskedastisitas.

Tabel 4.10 Hasil Uji Heteroskedastisitas

\begin{tabular}{|c|c|c|c|c|c|c|}
\hline \multicolumn{7}{|c|}{ Coefficients $^{a}$} \\
\hline & & \multicolumn{2}{|c|}{$\begin{array}{l}\text { Unstandardized } \\
\text { Coefficients }\end{array}$} & \multirow{2}{*}{$\begin{array}{c}\text { Standardize } \\
\mathrm{d} \\
\text { Coefficients } \\
\text { Beta }\end{array}$} & \multirow[b]{2}{*}{$\mathrm{t}$} & \multirow[b]{2}{*}{ Sig. } \\
\hline \multicolumn{2}{|c|}{ Model } & B & Std. Error & & & \\
\hline \multirow[t]{3}{*}{1} & (Constant) & -.204 & 1.969 & & -.103 & .918 \\
\hline & Customer Accounting & -.082 & .060 & -.276 & -1.356 & .183 \\
\hline & Customer Orientation & .129 & .073 & .357 & 1.755 & .088 \\
\hline
\end{tabular}

a. Dependent Variable: Kinerja Organisasi

\section{Sumber : Data diolah, 2019.}

Dari Tabel 4.10 terlihat bahwa nilai signifikansi tidak ada yang lebih kecil dari 0,05. Jadi disimpulkan bahwa tidak terdapat masalah heteroskedastisitas antara variabel independen dalam model regresi.

\section{Uji Regresi Linear Berganda}

Dalam penelitian ini analisis regresi linear berganda digunakan untuk melihat pengaruh antara variabel independen dan variabel dependen dengan skala pengukuran atau rasio dalam suatu persamaan linear.Analisis data yang digunakan dalam penelitian ini adalah analisis regresi linear berganda yang diolah dengan perangkat lunak SPSS versi 22. Ringkasan hasil pengolahan data dengan menggunakan program SPSS tersebut adalah sebagai berikut :

Tabel 4.11 Hasil Uji Regresi Linear Berganda

\section{Coefficients $^{\mathbf{a}}$}




\begin{tabular}{|l|c|c|c|c|l|}
\hline \multirow{2}{*}{ Model } & \multicolumn{2}{|c|}{$\begin{array}{c}\text { Unstandardized } \\
\text { Coefficients }\end{array}$} & $\begin{array}{c}\text { Standardized } \\
\text { Coefficients }\end{array}$ & & \multirow{2}{*}{ Sig. } \\
\cline { 2 - 6 } & $\mathrm{B}$ & Std. Error & Beta & $\mathrm{t}$ & Sig \\
\hline (Constant) & 3.356 & 3.773 & .889 & .380 \\
\hline Customer Accounting (X1) & .329 & .116 & .361 & $\begin{array}{c}2.84 \\
8\end{array}$ & .007 \\
\hline Customer Orientation (X2) & .582 & .141 & .524 & $\begin{array}{c}4.13 \\
8\end{array}$ & .000 \\
\hline
\end{tabular}

a. Dependent Variable: Kinerja Organisasi (Y)

\section{Sumber : Data diolah, 2019.}

Berdasarkan tabel 4.11 diatas maka diperoleh persamaan regresi sebagai berikut :

$$
Y=3,356+0,329 X_{1}+0,582 X_{2}
$$

Keterangan :

$$
\begin{array}{ll}
\mathrm{Y} & \text { : Kinerja Organisasi } \\
\mathrm{X}_{1} & \text { : Customer Accounting } \\
\mathrm{X}_{2} & : \text { Customer Orientation }
\end{array}
$$

Berdasarkan persamaan regresi diatas, maka dapat dijelaskan sebagai berikut :

\section{Konstanta (a)}

Persamaan diatas menunjukkan nilai konstanta (a) sebesar 3,356. Hal ini berarti bahwa jika variabel independen diasumsikan bernilai 0 (nol), maka variabel 


\section{Customer Accounting $\left(\mathrm{X}_{1}\right)$ terhadap Kinerja Organisasi}

Nilai koefisien regresi customer accounting untuk variabel $\mathrm{X}_{1}$ sebesar 0,329 dan bertanda positif. Hal ini berarti bahwa setiap kenaikan variabel customer accounting sebesar satu satuan, maka akan menaikkan variabel kinerja organisasi (Y) sebesar 0,329 dengan asumsi bahwa variabel bebas yang lain tetap.

\section{3. $\quad$ Customer Orientation $\left(\mathrm{X}_{2}\right)$ terhadap Kinerja Organisasi}

Nilai koefisien regresi customer orientation untuk variabel $\mathrm{X}_{1}$ sebesar 0,582 dan bertanda positif. Hal ini berarti bahwa setiap kenaikan variabel customer orientation sebesar satu satuan, maka akan menaikkan variabel kinerja organisasi (Y) sebesar 0,582 dengan asumsi bahwa variabel bebas yang lain tetap.

\section{Uji Koefisien Determinasi}

Koefisien determinasi $\left(\mathrm{R}^{2}\right)$ mengukur seberapa jauh kemampuan model dalam menerangkan variasi variabel dependen (Ghozali, 2011).Nilai $\mathrm{R}^{2}$ mempunyai interval antara 0 sampai $1\left(0 \leq R^{2} \leq 1\right)$.Semakin besar $R^{2}$ (mendekati 1$)$, semakin baik hasil untuk model regresi tersebut dan semakin mendekati 0 , maka variabel independen secara keseluruhan tidak dapat menjelaskan variabel dependen.Nilai $\mathrm{R}^{2}$ yang kecil berarti kemampuan variabel-variabel independen dalam menjelaskan variasi variabel dependen amat terbatas. Hasil uji koefisien determinasi dapat dilihat pada tabel dibawah ini :

Tabel 4.12 Hasil Uji Koefisien Determinasi

\begin{tabular}{|l|c|c|c|c|}
\hline \multicolumn{5}{|c|}{ Model Summary } \\
\hline Model & $\mathrm{R}$ & R Square & Adjusted R Square & $\begin{array}{c}\text { Std. Error of the } \\
\text { Estimate }\end{array}$ \\
\hline 1 & $.802^{\mathrm{a}}$ & .643 & .624 & 1.711 \\
\hline
\end{tabular}

\section{Sumber : Data diolah, 2019}

Dari hasil perhitungan dapat diketahui bahwa koefisien determinasi $\left(\mathrm{R}^{2}\right)$ yang diperoleh sebesar 0,643. Hal ini berarti 64,3\% kinerja organisasi dapat dijelaskan oleh variabel customer accounting dan customer orientation, sedangkan sisanya yaitu 35,7\% kinerja organisasi dipengaruhi oleh variabel-variabel lainnya yang tidak diteliti dalam penelitian ini. 


\section{Uji Hipotesis}

\section{Hasil Uji Signifikansi Parsial (t)}

Berdasarkan hasil pengujian tabel 4.11 diketahui nilai tabel pada taraf signifikansi $5 \%$ dengan persamaan berikut :

$$
\begin{aligned}
& \text { ttabel }=\mathrm{t}(\text { alpha } / 2 ; \mathrm{n}-\mathrm{k}-1) \\
& =\mathrm{t}(0,05 / 2 ; 40-2-1) \\
& =\operatorname{t}(0,025 ; 37) \\
& =2,026
\end{aligned}
$$

Maka pengujian parsial dari masing-masing variabel diuraikan sebagai berikut :

\section{Pengaruh Customer Accounting terhadap Kinerja Organisasi}

Tabel 4.13 Hasil Pengujian Hipotesis CA

\begin{tabular}{|c|c|c|c|c|c|}
\hline Hipotesis & $\mathbf{t}_{\text {hitung }}$ & $\mathbf{t}_{\text {tabel }}$ & Signifikan & $\begin{array}{c}\text { Alpha } \\
(\boldsymbol{\alpha})\end{array}$ & Keterangan \\
\hline $\mathrm{H}_{1}$ & 2,848 & 2,026 & 0,007 & 0,05 & Diterima \\
\hline
\end{tabular}

\section{Sumber : Data diolah, 2019}

Berdasarkan data olahan diatas diketahui thitung sebesar 2,848 dan tabel sebesar 2,026 dengan nilai signifikansi 0,007. Hasil perhitungan menunjukkan bahwa thitunglebih besar dari tabel atau 2,848 > 2,026 dengan nilai signifikansinya lebih kecil dari 0,05 atau $0,007<0,05$. Ini berarti variabel Customer Accounting berpengaruh terhadap Kinerja Organisasi, kesimpulannya $\mathrm{H}_{1}$ diterima.

\section{Pengaruh Customer Orientation terhadap Kinerja Organisasi}

Tabel 4.14 Hasil Pengujian Hipotesis CO

\begin{tabular}{|c|c|c|c|c|c|}
\hline Hipotesis & $\mathbf{t}_{\text {hitung }}$ & tabel & Signifikan & $\begin{array}{c}\text { Alpha } \\
(\boldsymbol{\alpha})\end{array}$ & Keterangan \\
\hline $\mathrm{H}_{2}$ & 4,138 & 2,026 & 0,000 & 0,05 & Diterima \\
\hline
\end{tabular}

\section{Sumber : Data diolah, 2019}

Berdasarkan data olahan diatas diketahui thitung sebesar 4,138 dan tabel sebesar 2,026 dengan nilai signifikansinya 0,000. Hasil perhitungan menunjukkan bahwa thitung lebih besar dari tabel atau 4,138 > 2,026 dan nilai signifikansinya lebih kecil dari 0,05 
atau $0,000<0,05$. Ini berarti variabel Customer Orientation berpengaruh terhadap Kinerja Organisasi, kesimpulannya $\mathrm{H}_{2}$ diterima.

\section{Hasil Uji Simultan (Uji F)}

Uji statistik F pada dasarnya menunjukkan apakah semua variabel independen atau variabel bebas yang dimasukkan dalam model mempunyai pengaruh secara bersama-sama terhadap variabel dependen atau terikat yang diuji pada tingkat signifikan $5 \%$ :

$$
\begin{aligned}
& F_{\text {tabel }}=F(\mathrm{k} ; \mathrm{n}-\mathrm{k}) \\
& =\mathrm{F}(2 ; 40-2) \\
& =\mathrm{F}(2 ; 38) \\
& =2,447
\end{aligned}
$$

Dalam hal ini untuk mengetahui apakah secara bersama-sama Customer Accounting dan Customer Orientation berpengaruh terhadap Kinerja Organisasi. Tabel dibawah ini menunjukkan hasil uji pengaruh simultan :

Tabel 4.15 Hasil Uji F

\begin{tabular}{|l|l|c|c|c|c|c|}
\hline \multicolumn{7}{|c|}{ ANOVA $^{\text {Sum of }}$} \\
\multicolumn{2}{|l|}{ Model } & $\begin{array}{c}\text { Mean } \\
\text { Squares }\end{array}$ & df & $\begin{array}{c}\text { Square } \\
\text { Sq }\end{array}$ & Sig. \\
\hline 1 & Regression & 194.840 & 2 & 97.420 & 33.295 & .000 \\
\cline { 2 - 7 } & Residual & 108.260 & 37 & 2.926 & & \\
\cline { 2 - 7 } & Total & 303.100 & 39 & & & \\
\hline
\end{tabular}

\section{Sumber : Data diolah, 2019}

Berdasarkan tabel diatas, diketahui bahwa Fhitung sebesar 33,295 dan Ftabel sebesar 2,447 dengan signifikansi sebesar 0,000. Hasil perhitungan menunjukkan bahwa $F_{h i t u n g}$ lebih besar dari $F_{\text {tabel }}$ atau 33,295 $>$ 2,447 dan signifikansinya 0,000<0,05, kesimpulannya $\mathrm{H}_{3}$ diterima. Artinya, secara simultan variabel Customer Accounting dan Customer Orientation berpengaruh terhadap Kinerja Organisasi. 


\section{Pembahasan}

\section{Pengaruh Customer Accounting terhadap Kinerja Organisasi}

Hasil analisis statistik variabel customer accounting diperoleh thitung sebesar 2,848 dengan tingkat signifikansi sebesar 0,007. Nilai signifikansi lebih kecil dari 0,05. Dapat disimpulkan bahwa customer accounting berpengaruh terhadap kinerja organisasi, sehingga hipotesis pertama yang diajukan diterima.

Berpengaruhnya customer accounting terhadap kinerja organisasi dikarenakan peran utama dari customer accounting yang merupakan bagian dari sistem informasi akuntansi adalah memfasilitasi perkembangan dan pelaksanaan dari strategi bisnis. Informasi akuntansi juga berperan dalam proses pengambilan keputusan yang berhubungan dengan perencanaan, tata kelola, pengarahan dan pengendalian organisasi (Valentine dan Devie, 2015). Dengan begitu, maka pelaksanaan strategi bisnis yang didukung oleh informasi akuntansi tersebut dapat mencapai kinerja organisasi yang diinginkan.

Hasil penelitian ini sejalan dengan Resource-Based View Theory yang merupakan salah satu perspektif yang memiliki kontribusi besar pada berbagai riset dan kajian manajemen strategik.Manajemen strategik diterapkan dalam bisnis atau badan usaha agar bisnis atau badan usaha dapat berjalan dengan baik dalam mencapai tujuan yang telah ditetapkan sehingga dapat meningkatkan kinerja organisasi.

Hasil penelitian ini juga mendukung hasil penelitian yang dilakukan oleh Valentine dan Devie (2015) serta Holm, Kumar dan Plenborg (2016) yang mengatakan bahwa customer accounting berpengaruh terhadap kinerja organisasi.

\section{Pengaruh Customer Orientation terhadap Kinerja Organisasi}

Hasil analisis statistik variabel customer orientation diperoleh thitung sebesar 4,138 dengan tingkat signifikansi 0,000. Nilai signifikansi lebih kecil dari 0,05. Dapat disimpulkan bahwa customer orientation berpengaruh terhadap kinerja organisasi, sehingga hipotesis kedua yang diajukan diterima.

Berpengaruhnya customer orientation terhadap kinerja organisasi hal ini dikarenakan customer orientation merupakan suatu tipe orientasi dimana kebutuhan konsumen menjadi dasar bagi suatu organisasi untuk merencanakan dan mendesain strateginya (Valentine dan Devie, 2015). Perusahaan yang berorientasi kepada pelanggan senantiasa berupaya menggali apa yang dapat disediakan perusahaan dengan 
membuat barang atau jasa yang terbaik. Penerapan customer orientation yang baik akan memberikan kontribusi pada peningkatan kinerja perusahaan.

Perusahaan dapat meningkatkan kinerja organisasi dengan cara berorientasi pada pasar. Perkembangan teknologi yang semakin canggih membuat informasi lebih mudah didapat, sehingga konsumen dengan mudah mendapatkan informasi mengenai produk yang mereka inginkan, baik dari segi rasa, harga dan kualitas produk (Andiyanto \& Sufian, 2017).

Salah satu kemudahan informasi dapat bersumber dari Ulasan Online dan Rating. Ulasan online adalah suatu tipe informasi produk yang dibuat oleh orang-orang yang pernah menggunakan produk tersebut (Susanto, 2018). Berdasarkan hasil online review dan rating yang bersumber dari Google ataupun dari Aplikasi makanan lainnya, ratarata konsumen setuju bahwa 40 pelaku usaha kuliner telah berorientasi pada pasar. Hal ini dapat dapat dilihat pada ulasan-ulasan yang konsumen berikan pada usaha mereka.Konsumen menyatakan bahwa rata-rata usaha kuliner telah memenuhi ekspektasi ataupun harapan mereka dengan memberikan produk yang dapat mereka terima baik dari segi harga, rasa, kualitas produk maupun kualitas pelayanan.

Hasil penelitian ini sejalan dengan Resource-Based View Theory.Menurut pandangan RBV aset berwujud dan aset tidak berwujud dapat menentukan kinerja organisasi.Customer orientation yang merupakan salah satu bentuk dari sumber daya intangible berupa budaya organisasi untuk menciptakan nilai lebih kepada pelanggan yang dapat meningkatkan kinerja organisasi.

Hasil penelitian ini juga mendukung hasil penelitian yang dilakukan oleh Rosiana (2017) dan Daud (2016) yang menyatakan bahwa customer orientation berpengaruh terhadap kinerja organisasi.

\section{Pengaruh Customer Accounting dan Customer Orientation terhadap Kinerja Organisasi}

Hasil pengujian secara simultan menunjukkan nilai signifikansi 0,000 atau lebih kecil dari 0,05 yang berarti bahwa hipotesis ke tiga diterima. Dapat disimpulkanbahwa variabel customer accounting dan customer orientation secara bersama-sama berpengaruh terhadap kinerja organisasi.

Berpengaruhnya customer accounting dan customer orientation terhadap kinerja organisasi dikarenakan semakin tingginya persaingan pada bisnis kuliner sehingga pelaku usaha harus memaksimalkan potensi mereka berdasarkan konsumen, karena 
konsumen merupakan bagian penting dalam organisasi dan berperan cukup besar dalam kelangsungan hidup organisasi (Valentine dan Devie (2015).Kinerja organisasi digunakan untuk mengukur dampak dari strategi perusahaan.Strategi perusahaan perlu diarahkan untuk menghasilkan kinerja organisasi baik berupa kinerja keuangan maupun kinerja pemasaran (Megawati, 2017).

Hasil penelitian ini sejalan dengan Resource-Based View Theory, menurut pandangan RBV strategi dilakukan dengan mengalokasikan sumber daya kepada kebutuhan pasar pada saat kemampuan perusahaan bersaing tidak mencukupi sehingga akan memberikan hasil yang lebih baik bagi perusahaan (Ricky, 2015).

Hasil penelitian ini juga mendukung hasil penelitian yang dilakukan oleh Valentine dan Devie (2015), Holm, Kumar dan Plenborg (2016) serta penelitian yang dilakukan oleh Rosiana (2017) dan Atmana (2014) yang mengatakan bahwa customer accounting sebagai strategic management accounting techniques dan customer orientation berpengaruh terhadap kinerja organisasi.

\section{KESIMPULAN}

\section{Kesimpulan}

Penelitian ini meneliti tentang pengaruh customer accounting sebagai strategic management accounting techniques dan customer orientation terhadap kinerja organisasi. Analisis dilakukan dengan menggunakan metode analisis regresi linier berganda dengan bantuan program SPSS Versi 22. Berdasarkan hasil uji regresi linier berganda secara parsial (uji t) diketahui pengaruh antara masing-masing variabel independen (customer accounting dan customer orientation) terhadap kinerja organisasi sebagai berikut :

1. Variabel Customer Accounting berpengaruh terhadap kinerja organisasi. Hal ini terjadi karena peran utama dari Customer Accounting adalah memfasilitasi perkembangan dan pelaksanaan dari strategi bisnis. Informasi akuntansi juga berperan dalam proses pengambilan keputusan yang berhubungan dengan perencanaan, tata kelola, pengarahan, dan pengendalian organisasi.

2. Variabel Customer Orientation berpengaruh terhadap kinerja organisasi. Hal ini terjadi karena para pelaku UMKM menggunakan Customer Orientation sebagai suatu strategi untuk keberlangsungan hidup perusahaan. Informasi pemasaran juga ikut 
membantu perusahaan untuk melacak konsumen sehingga kinerja organisasi dapat terjamin.

3. Variabel Customer Accounting dan Customer Orientation secara bersama-sama berpengaruh terhadap kinerja organisasi. Hal ini terjadi karena semakin tingginya persaingan pada bisnis kuliner sehingga pelaku usaha harus memaksimalkan potensi mereka berdasarkan konsumen, karena konsumen merupakan bagian penting dalam organisasi dan berperan cukup besar dalam kelangsungan hidup organisasi.

\section{DAFTAR PUSTAKA}

Al-Mawali, H., dan Lam, T. D. 2016. Customer Accounting and Environmental Uncertainty: Sequential Explanatory Study. International Review Of Management And Marketing. 6(3), 532-543.

Andiyanto, F., dan Sufian, S. 2017. Analisis Pengaruh Orientasi Pasar dan Inovasi Terhadap Keunggulan Bersaing dalam Rangka Meningkatkan Kinerja Bisnis. Universitas Diponegoro.

Atmana, H. 2014. Pengaruh Orientasi Pelanggan dan Koordinasi Interfungsional Terhadap Kinerja Organisasi dengan Kapabilitas Inovasi sebagai Mediator. Jurnal Bisnis Strategi. 23(1), 59-81.

Azmi, Z. (2018). Time driven activity based costing dan implementasinya pada jasa perawatan kesehatan, Jurnal akuntansi dan ekonomika, Vol.8 (1), 75-84.

Cadez, S., dan Guilding, C. 2008. An Exploratory Investigation Of An Integrated Contingency Model of Strategic Management Accounting. Accounting, Organization And Society. 33(7-8), 836-863.

Daud, A. 2016. Pengaruh Inovasi Layanan dan Keunggulan Posisional pada Kinerja Pemasaran. Jurnal Siasat Bisnis. 20(1), 66-78.

Ghozali, I. 2011. Aplikasi Analisis Multivariate Dengan Program SPSS. Semarang: BP Universitas Diponegoro.

Holm, M., Kumar, V., Plenborg, T. 2016. An Investigation Of Customer Accounting Systems As A Source Of Sustainable Competitive Advantage. International Accounting Journal. 18-30. 
Kaplan, R. S., dan Norton, D. P. 2000. Balanced Scorecard Menerapkan Strategi Menjadi Aksi. Jakarta: Erlangga.

Kaplan, R. S., dan Norton, D. P. 1992. The Balanced Scorecard Measures That Drive Performance. Harvard Business Review. 70(1), 71-79.

Kohli, A. K., dan Jaworski, B. J. 1993. Market Orientation: The Construct, Research Propositions, and Manajerial Implications. The Journal Of Marketing. 54(2), 1-18.

Megawati, R. 2017. Analisis Orientasi Kewirausahaan dan Orientasi Pasar terhadap Kinerja Usaha Melalui Kemampuan Manajemen Sebagai Variabel Intervening (Studi Pada UKM Sektor Kuliner di Medan Perjuangan). Jurnal Ilmiah Kohesi. 1-13. McManus, L., dan Guilding, C. 2008. Exploring The Potential Of Customer Accounting: A Synthesis of The Accounting And Marketing Literatur. Journal of Marketing Management. 24(7-8), 771-795.

Moeheriono. 2012. Pengukuran Kinerja Berbasis Kompetensi. Jakarta : PT. Rajagrafindo Persada.

Narver, J. C., dan Slater, S. F. 1990. The Effect Of A Market Orientation On Business Profitability. Journal Of Marketing. 54(4), 20.

Nazaruddin, I. 2015. Pengukuran Kinerja Non Financial Suatu Cara Meningkatkan "Value" Perusahaan. Akuntansi Dan Investasi. 1(1), 32-40.

Pawestri, N. 2018. "Kualitas Produk Jadi Kendala Pelaku UMKM Untuk Berkembang”. Tersedia: http://jogja.tribunnews.com/2018/12/20/kualitas-produk-jadikendala-pelaku-umkm-untuk-berkembang. Diakses pada 04 Februari 2019.

Ricky, L. R. 2015. Keuntungan Kompetitif Organisasi Dalam Perspektif Resources Based View (RBV). Jurnal ASE. 11, 1-2.

Ranto, P, W, D. 2016. Pengaruh Orientasi Kewirausahaan Terhadap Kinerja UMKM Bidang Kuliner di Yogyakarta. Jurnal Bisnis Manajemen Akuntansi Vol. 3 No. 2 Tahun 2016 Hal 1-11.

Rosiana, A. 2017. Pengaruh Orientasi Pasar Terhadap Kinerja Usaha Pada Usaha Mikro Kecil (UKM) Tempe Di Kota Bogor. Institusi Pertanian Bogor.

Rudianto. 2013. Akuntansi Manajemen. Jakarta: Salemba Empat.

Siregar, B. G. 2016. Penerapan Model Integrasi dalam Resources Based View Sebagai Strategi Bersaing Perusahaan dalam Pandangan Islam. Jurnal Akuntansi dan Bisnis. 2(1), 1-17.

Sugiyono. 2010. Metode Penelitian Bisnis. Bandung: Alfabeta. 
Sumiati. 2015. Pengaruh Strategi Orientasi Wirausaha dan Orientasi Pasar terhadap Kinerja Perusahaan UMKM Di Kota Surabaya. Jurnal Ilmu Ekonomi dan Manajemen. 31-34.

Surenggono dan Djamilah, S. 2016. Penerapan Akuntansi Manajemen Sebagai Variabel Mediasi Pengaruh Persepsi dan Pengetahuan Pelaku Usaha Kecil dan Menengah (UKM) terhadap Kinerja UKM. Universitas Jember.

Susanto, A. 2018. Pengaruh Ulasan Online di TripAdvisor terhadap Minat Menginap Generasi Milenial di Surabaya. Universitas Kristen Petra.

Valentine, L. dan Devie. 2015. Pengaruh Customer Accounting Sebagai Strategic Management Accounting Techniques dan Customer Orientation Terhadap Kinerja Organisasi. Business Accounting Review. 3(1), 338-349.

Wardhana, Aditya. 2017. Strategi Digital Marketing \& Implikasinya pada Keunggulan Bersaing UKM. Universitas Telkom. 1-11

www.ukmriau.com. Data UKM Kuliner di Riau. Diakses pada 07 Februari 2019. 